\title{
OCCUPATIONAL STRESS AND ITS INFLUENCE ON LABOR PERFORMANCE: A CASE STUDY ON ECOART STRUCTURE AND PRODUCTION
}

\author{
Francely do Nascimento Gomes ${ }^{1}$, David Barbosa de Alencar ${ }^{2}$, Fábio Soares de Oliveira ${ }^{3}$, Maria \\ Cristiane Bandeira Santos ${ }^{4}$, Valquiria Delani Alves Dias ${ }^{5}$ and Igor Felipe Oliveira Bezerra ${ }^{6}$
}

\author{
1,2,3,4,5 Blauro Cardoso de Mattos Higher Education Institute - FASERRA. Manaus-Amazonas, Brazil. \\ ${ }^{6}$ Nilton Lins University. Manaus-Amazonas, Brazil.
}

Email: franalex@hotmail.com, david002870@hotmail.com, fbsoares171@gmail.com, cristiane.engenheiracivil@gmail.com, valquiria.delani7@gmail.com, igorfelipe.dss@hotmail.com,

Received: Aug 20th 2019

Accepted: Aug 30th 2019

Published: December 02 ${ }^{\text {th }}, 2019$

Copyright (C2016 by authors and Galileo Institute of Technology and Education of the Amazon (ITEGAM).

This work is licensed under the Creative Commons Attribution International License (CC BY 4.0).

https://creativecommons.org/licen ses/by/4.0/

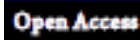

\begin{abstract}
This work is scoped to perform field work in Ecoart Structure and Production company to identify the factors that contribute to stress at work, and way to solve it. In this context the study notes that occupational stress can be caused by several factors present daily in organizations, damaging the working environment, productivity and so the company's profit. Stress index refers to the control of absences at times when workers are the scheduled time of the workday. The concept can also be better understood by the sum of the periods in which employees of a given organization absent from the work, including delays within their normal working hours. The method adopted for the realization of the research was descriptive. The typology of the adopted research covered three aspects: on the objectives treated is a deductive research; as the problem of approach was qualitative and quantitative; on the technical procedures, was literature. Through the survey it was observed that the valuation of intellectual capital can be a proposal for the reduction of occupational stress, as the successful application of this theory for the treatment of stress is to assimilate possible decision-making for managers of the resource area humans. At the end of this research are addressed recommendations that may be in guidelines for the management of people in organizations for the effective management of the causes and consequences of occupational stress, through the enhancement of intellectual capital.
\end{abstract}

Keywords: People Management. Occupational stress. Human capital.

\section{INTRODUTION}

The present study has as its central theme: "Occupational stress and its influence on workers' work performance: a case study in the company Ecoart structure and production", in this regard, it is noted that in recent years organizations in general They are going through an intense process of competition between customers and markets, where one of the differentials may be human talent.

Therefore, this "new" employee has been required to have a series of new skills and abilities, and how this relates in their work environment. The development of these criteria for the reduction of health ills in companies is directly related to the area of Human Resources that has gone from a simple personnel department to an agent of transformations in the organization [1].

Based on this concern, stress can be considered as the disease of the century, because this pathology can affect three areas of human life: physical, psychic and professional. From this context, the problem of this study focuses on the question: What is the influence of occupational stress on the work performance of workers in the company Ecoart Structure and Production. To answer this question, the general objective was to identify which factors contribute to stress at work.

This in turn divided into specifics: (1) Describe about the people management process; (2) list the main difficulties encountered by the Human Resources sector for managing stress at work; (3) identify the main factors that contribute to the development of work stress at Ecoart.

The present study is justified by the fact that occupational stress in the administrative area of the company Ecoart Structure and Production has become a major source of concern and is recognized as posing serious risks to workers' psychosocial wellbeing. Because workers spend much more time in their work environment each day than even with their families or doing 
activities of their own, the stress factor is becoming increasingly common among organizations.

However, it is noteworthy that despite maintaining a good work environment, with people willing to help each other, without strands, often the professional ends up frustrated, because his work is not recognized. Therefore, the lack of incentive and motivation combined with unsatisfactory wages are extremely important factors for occupational stress.

With this information, this work intends to be a contribution to the professionals of the administrative area, and organization as a whole, in order to awaken new stimuli to the development of works that aim to improve workers' health specifically regarding work stress.

From this perspective, it is hoped that this study will contribute to the discussion of this theme in the area of management knowledge as a support for effective prevention of stress at work, it is also believed that this research will serve as a contribution to future investigations necessary for the theme approach.

\section{BIBLIOGRAPHIC REFERENCE}

\section{II.1 PEOPLE MANAGEMENT}

The new perception of work relationship, people are partners of organizations which implies that each person is perceived as a microenvironment has specific goals and seeks in the organization their satisfaction [2].

According to [3] The People Management Process is a very important activity to be limited to only one corporate body. People management is a strategic issue for organizations. This role of managing people and competencies should be decentralized from just one department.

Each and every organization depends to a greater or lesser extent on human performance for success. For this reason, it develops and organizes a form of action on behavior that is conventionally called the people management model. Such a model is determined by factors internal and external to the organization itself, what distinguishes one model from another are the characteristics of its constituent elements and their ability to interfere in organizational life by giving it its own identity [4].

As studies of [3] various changes take place throughout the history of mankind, it can be said that throughout the twentieth century there were three distinct organizational ages (Table 01):

Table 1: Organizational Ages.

\begin{tabular}{|c|c|}
\hline INDICATORS & CONSEQUENCE \\
\hline $\begin{array}{c}\text { Classical } \\
\text { Industrial Era }\end{array}$ & $\begin{array}{c}\text { Period after the Industrial Revolution } \\
\text { where companies began to adopt the } \\
\text { bureaucratic organizational structure, with } \\
\text { emphasis on functional } \\
\text { departmentalization. }\end{array}$ \\
\hline $\begin{array}{c}\text { Neoclassical } \\
\text { Industrial Era }\end{array}$ & $\begin{array}{c}\text { Period extending from 1950 to 1990. The } \\
\text { bureaucratic model was resized by the } \\
\text { structuralist theory, when the classical } \\
\text { theory was replaced by neoclassical theory. }\end{array}$ \\
\hline Information & $\begin{array}{c}\text { Period that began in the 1990s to the } \\
\text { present day. The main characteristic of the } \\
\text { Information Age is change, which has } \\
\text { Eecome rapid, unforeseen, turbulent and } \\
\text { unexpected. }\end{array}$ \\
\hline
\end{tabular}

Source: Adapted from [3].
Faced with this scenario it can be observed that the organizational culture suffered a strong impact and during the historical process were privileged changes and innovations focused on the future. The changes are now fast and without continuity with the past. This brought an environmental context of turbulence and unpredictability.

In the studies of [6] People Management, however, it still constitutes a tendency that manifests itself more in the academic environment than in companies, since the most evident expression of its existence has been given by the revisions of the works related to human resources management and the courses being offered by specialized institutions.

People management should take place from the integrated view of people and key issues such as expectations about working relationships, the psychological contract between what people want from the company and what the employee wants [6]. Corroborating this context [7] developed an organization chart where Personnel Management performs the function of staff, that is, it now provides consulting, advisory and support services in the organizational structure (fig.01).

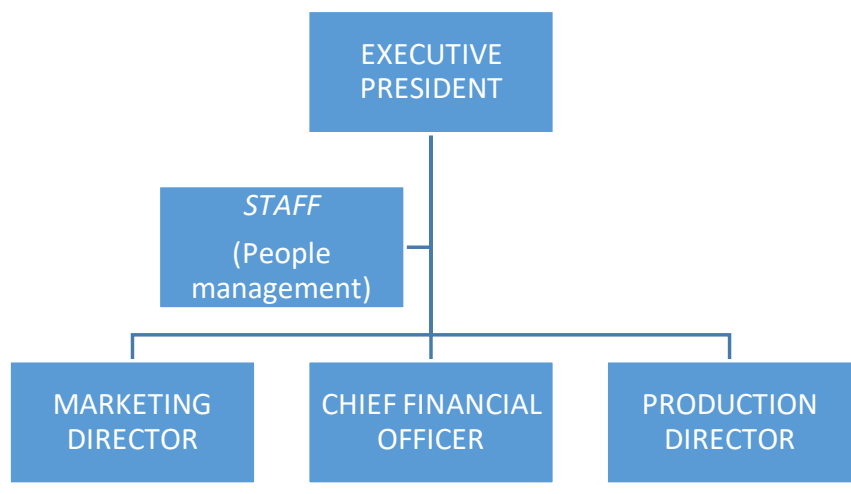

Figure 1: Functional organization chart of a company. Source: [7].

From this organization chart it is observed that there is an imperative need to adapt organizations to changes in the context in which they operate, considering that the topic is of great interest to contemporary managers. This adaptation imposes on the manager knowledge and the search for an understanding of nature, aspects that directly influence the organization such as the environment, existing resistances, communication processes and inserted cultural factors.

That is, the function of managing people and competencies should be directed to the other departments, since it has direct influence on the employee. Everything the company offers will be useless if this manager does not perform his role efficiently, if he does not understand that the job is primarily dealing with people [8].

\section{II.1 OCCUPATIONAL STRESS}

However, the process of managing people is a very important activity to be limited to only one body of the company. People management is a strategic issue for organizations, and it is these strategies that can somewhat interfere with the challenges of Human Resource Management.

In this sense, it is appropriate to conceptualize the word stress, so it is pointed out in this study that this word is derived from the term stress (English), which means a set of reactions of the body to various aggressions of origin, the root of the word stress comes from Latin stringers and is meant to squeeze. 
Once the meaning of the word has been punctuated, it is noteworthy that nowadays organizations are intensifying competition among themselves for customers and markets, and also competing for the most important resource: human talent. Given this scenario, workers have been required new skills and abilities, as well as different ways of producing and relating to work, associating the important value for health [9].

Selye was the precursor in stress-related studies. In her studies, she observed that stress produced defense and adaptation reactions to the stressor. These reactions have three phases or stages, as follows:

I. Alarm phase: consists of a very rapid phase of orientation and hazard identification, preparing the body for the reaction itself, i.e. the resistance phase. Many times, these feelings do not identify as stress, which is why many do not realize that they are in this state;

II. Resistance phase: It is a phase that can last for years. It is the way the body adapts to the new situation. It is part of the individual's total stress and proceeds in two basic ways: synoxic (tolerance and acceptance) and catotoxic (counter, nonacceptance). This occurs when the person tries to adapt to the new situation by restoring the internal balance; and,

III. Exhaustion phase: consists of an extinction of resistance, either by the disappearance of the stressor, the aggressor, or by the tiredness of the resistance mechanisms. So, it is in this case that the result will be the disease or even a breakdown.

Thus, stress can be understood as the point at which the individual cannot control their internal conflicts, generating an excess of energy, resulting, consequently, fatigue, tiredness, sadness, euphoria; its organic complex undergoes changes in the face of chemical transformations that occur before this emotional state [10].

Stress manifests itself in two ways: distress, or stress of defeat, which is stress as we know it on its negative side; and eustress, considered positive stress. Contributing in this context [11] teach that, in the sense of understanding the stress arising from work situations, which is called by the author as occupational stress. It is a reaction of the individual to his work environment that somehow affects him. These threats can be understood as stressors that characterize an unproductive relationship between the structure of the individual and his occupational environment, demonstrating that excessive changes are being directed at the worker and that he is not psychologically prepared to internalize. them positively.

Within this context [12] describe that they define occupational stress as an unpleasant emotional state, due to tension, frustration, anxiety, emotional exhaustion due to aspects of work defined by individuals as threatening. Occupational stress can be defined from the focus on organizational stressors that allow us to differentiate between two types of study: occupational stress and stress in general.

According to [10] sources of stress are termed as stressors, and can be defined as any event that confuses, frightens or excites the individual, which in turn can be of internal and / or external origin.

Based on this context it is observed that the association between stressors will determine whether he will develop excessive stress or not.

\section{MATERIALS AND METHODS}

In general, this work can be classified as applied research, as it is based on the application of theory already elaborated. To obtain the purposes foreseen in this research, the investigation procedure employed in this study was the qualitative-quantitative research, which according to [13] allows to obtain information of greater depth and at the same time greater amplitude of the investigated problem.

In this article, we used the descriptive method where [14] state that: "Descriptive reasoning has the characteristics of observing, recording, analyzing, describing and correlating facts or phenomena without manipulating them, trying to find out precisely how often a phenomenon occurs and its relation to other factors".

As for the technical procedures used for the formation of this work, the bibliographic research was used. For [14], the bibliographic research "aims to collect information and prior knowledge about a problem for which an answer is sought or about a hypothesis that one wants to experiment". It was also necessary to use a field research, as [13], "is characterized by investigations in which, in addition to bibliographic and / or documentary research, data are collected from people using different types of information. search".

\section{STUDY APPLICATION}

Data collection occurred through field research, applying a questionnaire with clear and objective questions to 10 employees of the administrative sector of the company Ecoart Structure and Production in the city of Manaus. The invitation to participate in the study will be made by the researcher in that company for each individual who fulfills the inclusion criteria.

Only the researcher will be responsible for listing the names of possible participants, so that it is guaranteed that each individual participates only once in the research, thus not generating duplicate data.

Subsequently, participants will be identified by numeric codes to ensure that each participant's identity is preserved. This relationship will be destroyed shortly after the database has been assembled, so that its analysis is processed only with the numeric code of the participants.

For the application of the questionnaires, the following criteria were taken into account: being an employee of a particular company and developing its activities for at least one year. The collected data will be passed to Excel for tabulation, analysis and verification of the results.

Participation in the study was voluntary, leaving the participant free if they do not want to answer any questions. The study participant is guaranteed the right to withdraw from participation in the research at any time, including during the completion of the research instrument. It is of great importance to clarify to the participant about his anonymity in the referred study. Professionals will be informed about the conduct of this research and the study will not interfere with the routines and operational and administrative activities of the company (data collection).

\section{RESULTS / DISCUSSIONS}

The company Ecoart Structure and Production Ltda., Founded in 04/04/2010, has as founding partner Mr. Jorcenês Batalha Marinho. The company grows in the market, this can be observed, as it began its activities as a choice of Simples Nacional, and nowadays it becomes Presumed Profit, in a limited legal form. Ecoart entered the market with the mission of sophistication and improvement in the aluminum structure assembly business to achieve full satisfaction of its customers, fully meeting their needs and expectations through the supply of products and services in the assembly area. event productions, aiming at the search for better results. Among its main products are the lighting fixtures for shows 
and spaces, with moving's, acl's and others, as well as aluminum structures in various sizes that enable their applications in various uses.

Ecoart's functional organization chart is classified as vertical because it represents the organs and lines that make the hierarchical and communication link between the sectors of the enterprise.

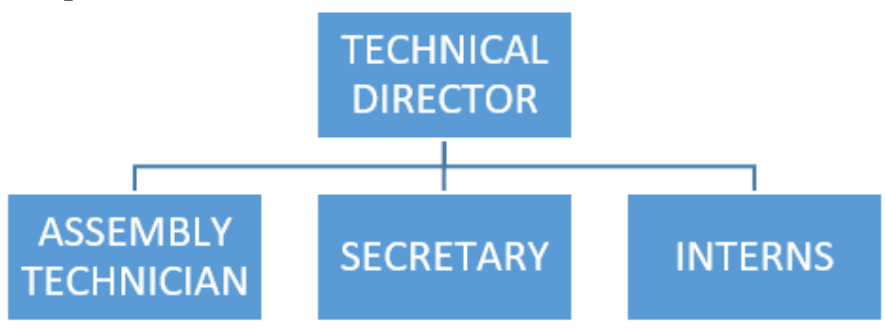

Figure 2: Ecoart Functional Organization Chart. Source: Authors, (2019).

Regarding the level of education of employees, it was identified that only $20 \%(\mathrm{n}=2)$ of their staff have completed higher education and $70 \%(\mathrm{n}=7)$, opens a caveat that the rest who are attending higher education (Fig. 3-5). This data was provided by company management.

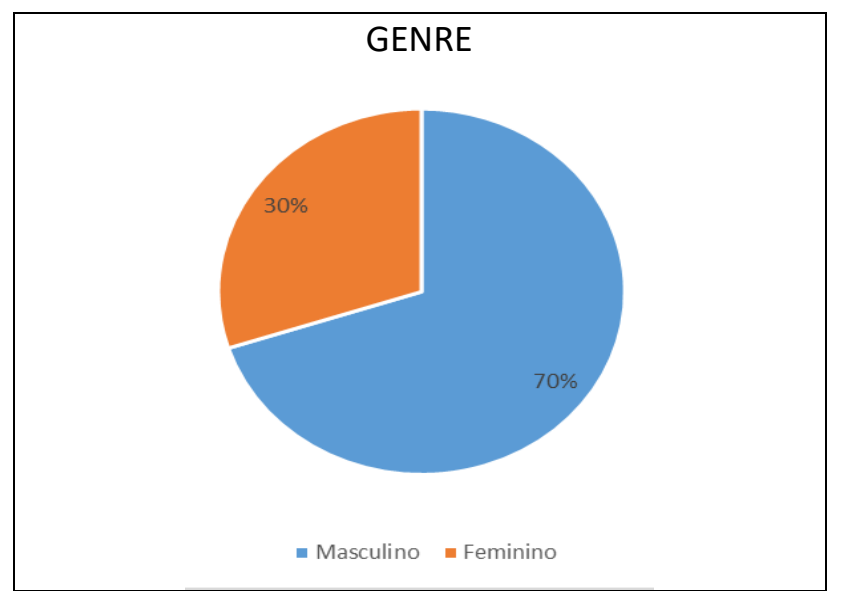

Figure 3: Genre.

Source: Authors, (2019).

Through this graph it is observed that the functions that require rationality and strength are preferably performed by the male gender, however, the employees of the company perform the functions that require greater organization, special care, obedience and servility, thus legitimizing a thought historically crystallized by society.

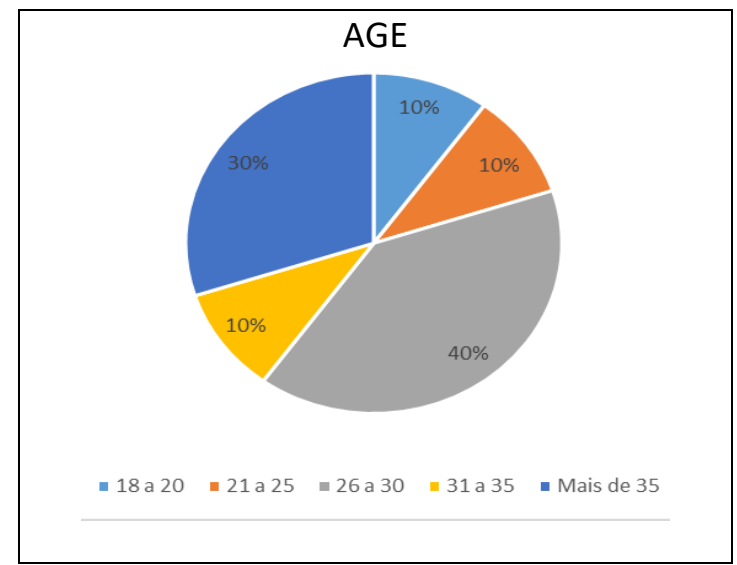

Figure 4: Age.

Source: Authors, (2019).
Companies noted that the important competitive differential in the organizations market is people, which is like human capital. According to [7] capital is mobile, but once the organization has acquired it and may have invested in it, it will want to secure it.

In agreement with this argument [8], when analyzing the organizational reality more closely, we verified our tendency to consider, as fair and adequate, differentiation criteria that indicate the level of value addition from the person to the company. By explaining more naturally and spontaneously in our society the people who are most capable of contributing to us or our organization are most valued.

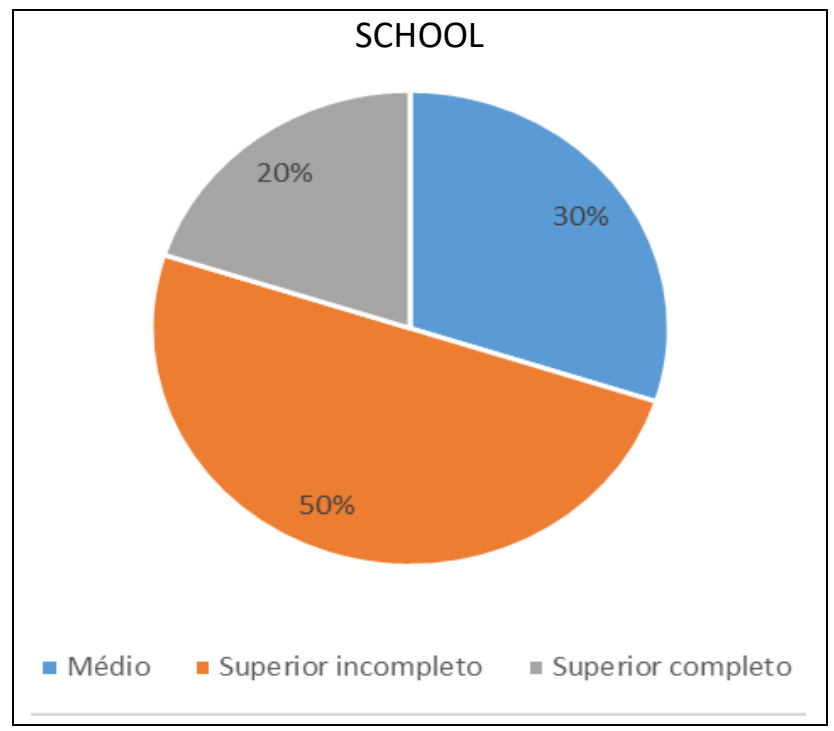

Figure 5: Schooling

Source: Authors, (2019).

In this sense Ecoart is looking for people who have the skills, competencies to reach the competitive market and show the difference with their ideas creating and recreating in order to acquire profit and be the reference in the organizational economy. But in order to achieve all the goals and make your business unique, companies must invest and recognize the value people get.

Figure 5 shows that education is the engine of growth and productivity and unfortunately in Brazil it is a deficient, bureaucratic process that needs to be improved to the needs of those who need to study. Ecoart believes that acting together with its partners in education and qualification will achieve better results and become a better company. Within this context, it is observed that most of Ecoart's employees are male, with an average age of 26 to 30 years, and have completed higher education.

According to Ecoart, stress concerns have been increasing, as this fact has been playing an important role in the work development process, which can lead to the incapacity and death of employees.

Thus, it is understood that occupational stress management programs can be developed by Ecoart focusing on the organization of work and / or worker. According to [10], intervention measures can be described as follows (Table 2). 
Table 2. Intervention measures.

\begin{tabular}{|c|c|}
\hline RELATIONSHIP & ACTION \\
\hline Workers & $\begin{array}{l}\text { - To seek leisure and fulfillment at work, in personal and social life, with the awareness that such pursuit is } \\
\text { fundamental for coping and overcoming stress; } \\
\text { - Developing physical activities regularly, controlling food, resting and maintaining social activities are some } \\
\text { of the factors suggested by several authors as supporting in controlling and coping with stress; } \\
\text { - Understand that human beings act, think and feel differently from each other, that crises drive important } \\
\text { achievements and changes in people's lives, thereby investing in personal skills and abilities, strengthening } \\
\text { themselves physically, psychically and socially. and allowing yourself a better quality of life. }\end{array}$ \\
\hline Teams & $\begin{array}{l}\text { - Conduct interviews with employees in order to know the causes of job satisfaction and dissatisfaction; } \\
\text { - Create institutional spaces to support members of multidisciplinary teams, providing greater interaction and } \\
\text { interaction between people, creating discussion groups and updating references that involve the theme of } \\
\text { interpersonal relationships in the workplace, to provide support to the worker; } \\
\text { - Encourage the relationship between the manager and other team members, understanding that when the } \\
\text { worker is heard and respected, the tasks within his / her competence are performed with greater involvement, } \\
\text { responsibility and satisfaction, consequently, with less physical and mental stress. }\end{array}$ \\
\hline Organizations & $\begin{array}{l}\text { - Immediate hiring of human resources to reduce the amount of service performed by each employee. In this } \\
\text { way the professional will perform his / her function more easily and certainly the quality of the service will } \\
\text { be superior; } \\
\text { - Accompany and guide the professionals, clarifying the objectives, the philosophy, the dynamics and the } \\
\text { functioning of the Basic Health Units, Hospitals and other workplaces; } \\
\text { - Develop interdisciplinary support and stress prevention programs to improve the quality of life of health } \\
\text { workers by establishing strategies that minimize the problems highlighted by these professionals. Such } \\
\text { programs should preferably be conducted in the environments and times of job; } \\
\text { - Implement a stress control program, informing, training and teaching people how to deal with stressful } \\
\text { situations, focusing on interacting with events; } \\
\text { - Create continuing education programs, aimed at technical training and the development of critical, ethical, } \\
\text { political sense and generating motivation for greater integration and division of responsibilities and } \\
\text { difficulties in the service; and, } \\
\text { - Make workers aware of the importance of leisure and social support in coping and overcoming stress. }\end{array}$ \\
\hline
\end{tabular}
Source: Authors, (2019).

Against this background Ecoart can make use of these strategies, thereby increasing the frequency and intensity of positive emotional states. However, it is noteworthy that occupational stress can be linked to the work environment in which the individual is inserted. Environment means not only ergonomic or spatial aspects, but mainly issues related to work and organizational characteristics.

\section{FINAL CONSIDERATIONS}

With this research can be said that occupational stress is based on the identification of various causes present within an organization, which are related to the external world of the employee. Even at this juncture, the term stress emerges as a managerial issue that should be addressed by the People Management area. Faced with this scenario the role of managers needs to be at the center of the change process, actively participating as generators of the successful company.

In order to contain occupational stress in companies, it is necessary for the organization to have a Human Resources administration, to invest in social benefits plans for workers, in order to provide another way of compensation to them, also reaching other types of compensation. benefits.

It is noteworthy that the results can only be maximized if such suggestions are used in a manner compatible with the reality of the company, considering the characteristics of the structure, processes and culture. Given this line of thought, it is considered that one of the relevant contributions intended by this work is to glimpse the appreciation of human potential within organizations.

For the academic, the study about occupational stress becomes important, mainly, because the national marketing scenario is increasingly demanding and lacking qualified professionals, research can also contribute to the generation of information-based research sources. collected in current articles and works published with the purpose of informing the real practice of people management and the importance of valuing human capital.

Finally, it is important to recommend that people management professionals be vigilant at the first signs of excessive tension among workers. In order to keep the work environment in balance, it is also important to identify and control practices that are known to be obsessive-compulsive, which are often even encouraged by organizations.

\section{REFERENCES}

[1] Claro, M.A.P.M.; Nickel, D.C. Gestão de Pessoas. In: Coleção Gestão Empresarial, 2002.

[2] Penatti, I.; Zago, J.S.; Quelhas, O. Absenteísmo: As Consequências na Gestão de Pessoas. In: III SEGeT - Simpósio de Excelência em Gestão e Tecnologia. 2006.

[3] Lima, Maria Eduarda Barbosa, et al. Ética em contabilidade: um estudo sobre a percepção dos discentes acerca da ética profissional. Revista de Gestão e Contabilidade da UFPI, 2015, 1.2.

[4] Ribas, Andréia; Duran, Cristiana. Gestão de pessoas nas organizações. 2015.

[5] Gil, Antonio Carlos. Gestão de Pessoas. São Paulo: Atlas, 2010. 
[6] Albuquerque, Lindolfo Galvão de; Leite, Nildes Pitombo; Silva, Leilianne Michelle Trindade da. Estimulando o debate sobre a gestão estratégica de pessoas. 2009.

[7] Ribeiro, Antonio de Lima. Gestão de pessoas. Editora Saraiva, 2017.

[8] Xavier, Ricardo. Gestão de Pessoas na Prática. São Paulo: Gente, 2006.

[9] Sauter, S. L. As constantes mudanças no trabalho e o bem-estar dos profissionais. V Congresso de Stress da International Stress Management Association - ISMA/BR e VII Fórum Internacional de Qualidade de Vida no Trabalho. Porto Alegre, 2005.

[10] Segantin, B.G.O; Maia, E.M.F.L. Estresse vivenciado pelos profissionais que trabalham na saúde. [Monografia]. INESUL: Londrina, 2007.

[11] Pereira; L.Z.; Zille, G.P. O Estresse no trabalho: uma análise teórica de seus conceitos e suas inter-relações. In: Gestão e sociedade [on line]. 2012.

[12] Benke, M.R.P.; Carvalho, E. Estresse x qualidade de vida nas organizações: um estudo teórico. [Artigo]. FESURV: Rio Verde, 2006.

[13] Vergara, Sylvia Constant. Projetos e Relatórios de Pesquisa em Administração $10^{\circ}$ ed. Atlas 2009.

[14] Lakatos, E. Maria; Marconi, Marina. de Andrade. Fundamentos de metodologia científica: Técnicas de pesquisa, 2010, 